\title{
POPULATION STRUCTURE OF Nacella concinna (STREBEL, 1908) (GASTROPODA - NACELLIDAE) AT ADMIRALTY BAY, KING GEORGE ISLAND, ANTARCTICA, IN AUSTRAL SUMMER 2010/2011.
}

http://dx.doi.org/10.4322/apa.2014.107

\section{Maria Isabel Sarvat de Figueiredo*, Helena Passeri Lavrado}

Laboratório de Bentos, Departamento de Biologia Marinha, Instituto de Biologia, Universidade Federal do Rio de Janeiro, Prédio do CCS - Bloco A, llha do Fundão, CEP 21949-900, Rio de Janeiro, RJ, Brazil

*e-mail: belfig@gmail.com

\begin{abstract}
Antarctic intertidal zones are extremely stressful environments, and the limpet Nacella concinna (Strebel, 1908), colonize those areas at Admiralty Bay, King George Island. This species has the potential to be a biomonitor, since it suffers the direct effects of environmental variations and anthropic impacts. In the summer of 2010/2011, specimens of $N$. concinna were collected in three sites in Admiralty Bay, in order to investigate its population structure variability. Most individuals were larger than $20 \mathrm{~mm}$, i.e, most of them were adults, with positive allometric growth. In general, sex ratio was 1.5 females to one male. Limpet population structure near the Brazilian station did not present any atypical values, but, temporal analyses are necessary for more precise evaluation. Spatial differences found not only should be considered a response to natural physical factors such as wave action and food availability, but also to biological factors, such as seagull predation.
\end{abstract}

Keywords: Nacella concinna, Population Structure, Admiralty Bay

\section{Introduction}

Antarctic intertidal zone is extremely stressful, since it is often subject to large environmental variation, such as freezing and ice foot in winter, and melt water runoff in summer (Weihe \& Abele, 2008). The gastropod Nacella concinna (Strebel, 1908), is the most conspicuous invertebrate of the intertidal megafauna (Kim, 2001), colonizing throughout most of the intertidal zone of Admiralty Bay. However, the knowledge about its ecology is still incipient, and the knowledge about population dynamics is fundamental to understand the ecosystem processes (Jones et al., 2007) and to evaluate the meaning of environmental changes, increasingly evident in the Southern Ocean. The present study aimed to describe the natural spatial variability of that gastropod population structure in order to establish a baseline for environmental monitoring.

\section{Materials and Methods}

In the summer of 2011, 3 sites were chosen in Admiralty Bay, encompassing areas under the influence of ice, anthropic activities (Brazilian Station), and far from both, where specimens of $N$. concinna were counted in transects parallel to the shore at low tide. Limpets were collected until the number of individuals reached at least 100 at each site, and they were fixed in $10 \%$ formaldehyde. The sex of each individual was determined, and shell length, body weight, and gonad weight were measured. The gonadsomatic index (GSI) was determined according to formula: GSI $=(\text { gonad weight/total soft body weight })^{\star} 100$. To verify the contribution of biometric variables on variance populations, a Principal Component Analysis (PCA) was performed. Homogeneity of variances was checked by Cochran's test, and data was log-transformed whenever necessary. Shell length (SL) and wet weight (W) were used 
to plot regression curves $\left(\mathrm{W}=\mathrm{a} \cdot \mathrm{SL}^{\mathrm{b}}\right)$. To verify differences in sex ratio, Chi-Square test was performed, and a two-way ANOVA was used for differences in size and weight between sites and sexes.

\section{Results}

The mean size and weight of $N$. concinna significantly varied among sites $(\mathrm{F}=21.62 ; p<0.0001$ and $\mathrm{F}=16.12$; $p<0.0001$, respectively). The smallest individuals occurred at EACF (Brazilian station), while the lightest ones were found at Botany Point (Figure 1). Furthermore, no statistical differences were found between mean size and weight of male and female limpets $(\mathrm{F}=0.30 ; p=0.57)$ and no interaction between sites and sex was found $(\mathrm{F}=1.40$, $p=0.24)$.

Females outnumbered males in the population $(\sim 1.5$ females / 1 male), being the sex ratio significantly different from 1:1 $\left(\chi^{2}=11.44 ; \mathrm{p}<0.001\right)$.

In summer, specimens showed a positive allometric growth (Table 1). The PCA showed an evident distinction of Punta Plaza population (Figure 2), in which length and Gonadosomatic Index (IGS) presented the highest contributions to the first axis $(90,40 \%$ and $90,45 \%$, respectively).

\section{Discussion and Conclusion}

Spatial differences in size and weight seem to be related, among other factors, to variations in food availability, since growth rates are improved by better food offer. The

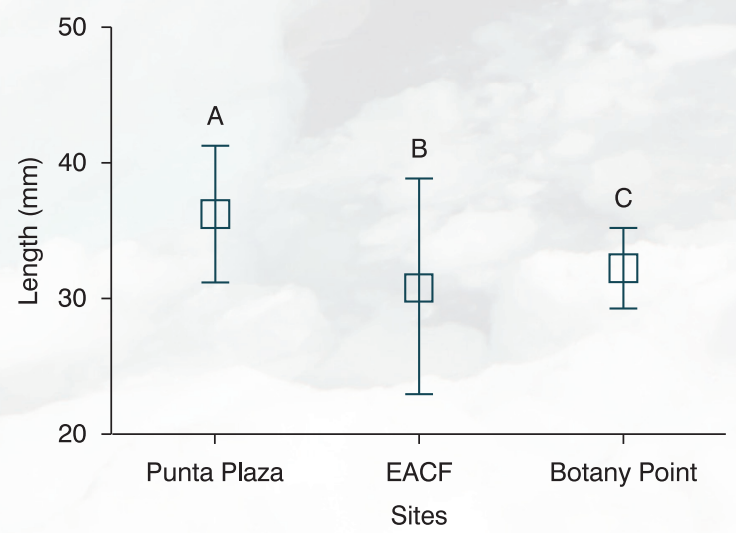

largest individuals were found at the sites which presented the highest values of epilithic chlorophyll $a$ (Lavrado, unpublished data). Environmental stress at intertidal zones may be one feasible explanation for the scarceness of limpets with shell size smaller than $20 \mathrm{~mm}$ in the population. Small specimens have high surface-to-volume ratios, being unable to tolerate desiccation conditions, thermal and osmotic stress (Weihe \& Abele, 2008). So, small limpets are at a disadvantage if compared to the large ones, probably being restricted to lower intertidal levels, or to the sublittoral zone. On the other hand, an evident distinction was observed for Punta Plaza population, in which gonadal development seems to be the main factor for this observation, since weight and IGS were the variables with major contribution. In addition, positive allometric growth found in all populations of this study can be a result of the high gonad weight, since summer is a reproductive period of this species (Kim, 2001).

Finally, Kim (2001) also found more females than males in the population of Maxwell Bay, adjacent to Admiralty

Table 1. Weight-length relationship of individuals of $N$. concinna collected at Admiralty Bay, in the summer of $2010 / 2011 . \mathrm{W}(\mathrm{g})=\mathrm{aL}(\mathrm{mm})^{\mathrm{b}}$.

\begin{tabular}{cccc}
\hline Sites & $\begin{array}{c}\text { Total } \\
\text { number }\end{array}$ & $\begin{array}{c}\text { Weight-length } \\
\text { relationship } \\
\text { Slope } \mathbf{( b )}\end{array}$ & $\begin{array}{c}\text { Coefficient of } \\
\text { determination } \\
\left.\mathbf{( R}^{2}\right)\end{array}$ \\
\hline Punta Plaza & 133 & 3,577 & 0,943 \\
EACF & 74 & 3,349 & 0,981 \\
Botany Point & 92 & 3,515 & 0,883 \\
\hline
\end{tabular}

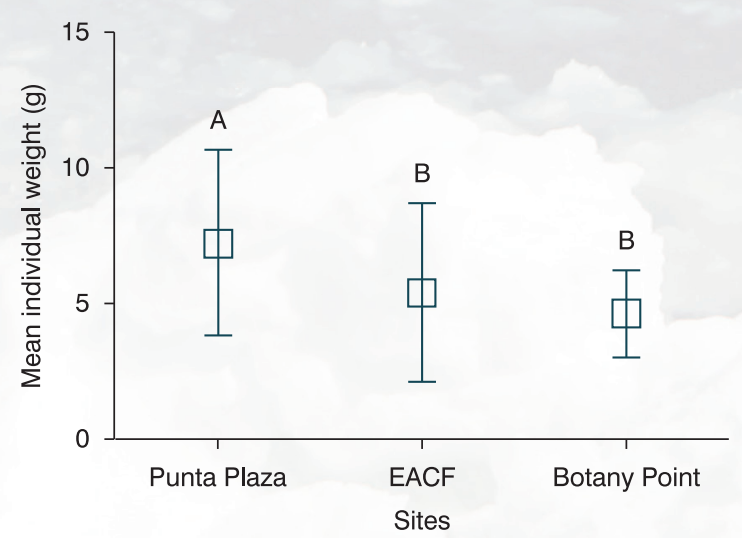

Figure 1. Shell length and mean individual weight of individuals of $N$. concinna collected in the intertidal zone of Admiralty Bay in the summer of $2010 / 2011$. Different letters indicate statistically different means. 


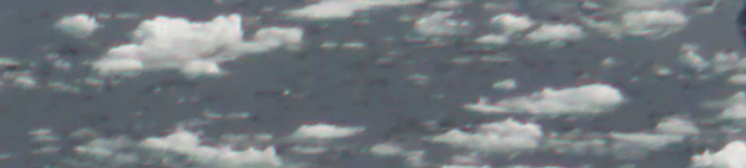

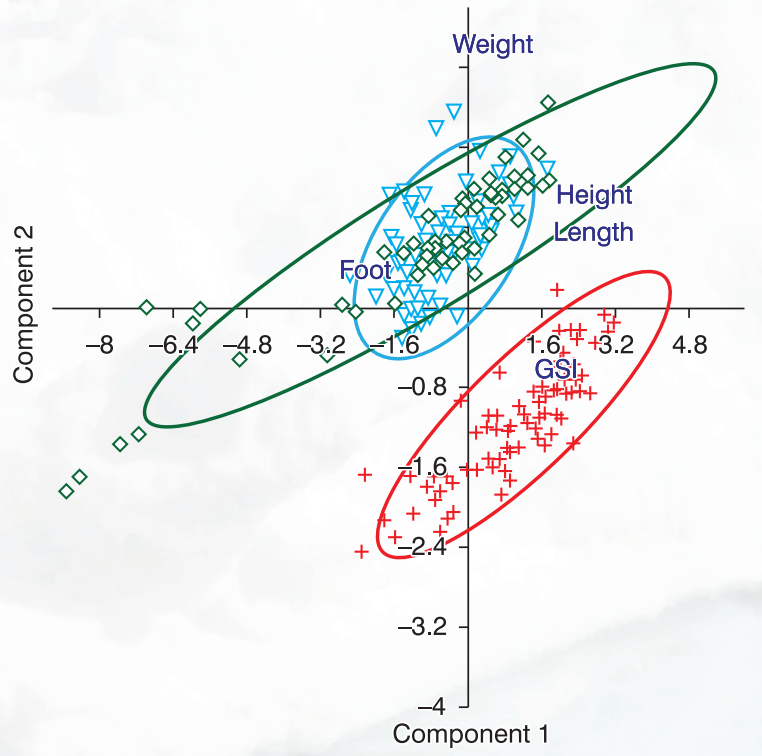

- Punta Plaza EACF Botany Point

Figure 2. Principal Component Analysis (PCA) using the main population variables of $N$. concinna (austral summer 2010/2011).

Bay. This author suggests that, in the case of N. concinna, the dominance of females in the intertidal population may be explained by the migratory behavior. Moreover, some of the spatial differences found may have occurred as a result of predation by the Kelp gull Larus dominicanus, since this bird is a significant predator of N. concinna (Barbieri, 2008), and its nests were observed nearby the sample sites, specially Punta Plaza and Botany Point.

Therefore, our results suggest that differences found between sites seem to be related to a response to food availability, physical stress and predation rates in the intertidal zone. Positive allometric growth can be related to high gonadal development, since summer is the reproductive period for this species. Lastly, since the Brazilian Station did not show either abnormal or discrepant values for all the parameters analyzed, its presence apparently does not interfere in the N. concinna population. However, temporal studies become necessary for a better evaluation.

\section{Acknowledgments}

This work integrates the National Institute of Science and Technology Antarctic Environmental Research (INCT-APA) that receives scientific and financial support from the National Council for Research and Development (CNPq process: $n^{\circ}$ 574018/2008-5) and Carlos Chagas Research Support Foundation of the State of Rio de Janeiro (FAPERJ $n^{\circ}$ E-16/170.023/2008). The authors also acknowledge the support of the Brazilian Ministries of Science, Technology and Innovation (MCTI), of Environment (MMA) and InterMinistry Commission for Sea Resources (CIRM). The first author thanks to $\mathrm{CNPq}$ for master fellowship under process $n^{\circ}$. 132125/2010-2.

\section{References}

Barbieri, E. (2008). Diversidade da dieta e do comportamento do Gaivotão Antártico (Larus dominicanus) na Península Keller, Ilha Rei George, Shetland do Sul. O Mundo da Saúde, 32(3):302-307.

Jones, D.O.B.; Bett, B.J. \& Tyler, P.A. (2007). Depth-related changes to density, diversity and structure of benthic megafaunal assemblages in the Fimbul ice shelf region, Weddell Sea, Antarctica. Polar Biology, 30:1579-1592.

Kim, J. (2001). Seasonality of marine algae and grazers of an Antarctic rocky intertidal, with emphasis on the role of the limpet Nacella concinna Strebel (Gastropoda: Patellidae). Tese de Doutorado em Biologia/Química, Universidade de Bremen. 120p.

Weihe, E. \& Abele, D. (2008). Differences in the physiological response of inter- and subtidal Antarctic limpets Nacella concinna to aerial exposure. Aquatic Biology, 4:155-166. 